\title{
Tenascin Demarcates the Boundary between the Myelinated and Nonmyelinated Part of Retinal Ganglion Cell Axons in the Developing and Adult Mouse
}

\author{
Udo Bartsch, ${ }^{1}$ Andreas Faissner, ${ }^{2}$ Jacqueline Trotter, ${ }^{2}$ Ulrich Dörries, ${ }^{1}$ Susanne Bartsch, ${ }^{1}$ Hasan Mohajeri, ${ }^{1}$ and \\ Melitta Schachner ${ }^{1}$ \\ 1Department of Neurobiology, Swiss Federal Institute of Technology, Hönggerberg, 8093 Zürich, Switzerland and \\ ${ }^{2}$ Department of Neurobiology, University of Heidelberg, 69 Heidelberg, Germany
}

\begin{abstract}
The molecular determinants controlling the topographically restricted distribution of neural cells in the mammalian CNS are largely unknown. In the mouse, myelin-forming oligodendrocytes are differentially distributed along retinal ganglion cell axons. These axons are myelin free intraretinally and in the most proximal (i.e., retinal) part of the optic nerve, but become myelinated in the distal (i.e., chiasmal) part of the optic nerve. Tenascin protein and mRNA are detectable in increased amounts at the retinal end of the developing optic nerve before the arrival of oligodendrocyte progenitor cells and are restricted to this region in the adult optic nerve. Tenascin is a nonadhesive substrate for oligodendrocytes and their progenitor cells in vitro when offered as a substrate in choice with polyornithine. These observations suggest that tenascin is critical for the establishment and maintenance of the restricted distribution of myelin-forming oligodendrocytes along retinal ganglion cell axons of the mouse.

[Key words: astrocyte, myelination, oligodendrocyte progenitor cell, oligodendrocyte, PDGF $\alpha$-receptor, tenascin]
\end{abstract}

During development, oligodendrocyte progenitor cells migrate into the optic nerve from the chiasmal end (Small et al., 1987; Fulton et al., 1992; Pringle et al., 1992) and thus serve to distribute oligodendrocytes along retinal ganglion cell axons. In most mammalian species, oligodendrocytes are, however, differentially distributed along these axons. Almost all of them are myelinated in the optic nerve proper but they remain unmyelinated intraretinally and in the most proximal part of the nerve (Hildebrand et al., 1985; Bartsch et al., 1989; Perry and Lund, 1990). Thus, vision is not impaired by the presence of myelin in the retinal nerve fiber layer. Retinal ganglion cell axons are, however, myelination-competent along their entire length. The proximal and normally unmyelinated part of these axons becomes myelinated by Schwann cells or oligodendrocytes under

\footnotetext{
Received May 4, 1993; revised Oct. 22, 1993; accepted Dec. 31, 1993.

We are grateful to Drs. H. S. Mudhar, N. P. Pringle, and W. D. Richardson for communicating results prior to publication, Drs. M. C. Raff and W. D. Richardson for helpful discussions and comments on the manuscript, Drs. N. J. Cowan, C. Lai, and W. D. Richardson for providing the GFAP, MAG, and PDGF $\alpha$-receptor cDNA clone, respectively, Drs. Frank Kirchhoff and Penka Pesheva for providing MAG and laminin antibodies, and Martina Keggenhoff for excellent technical assistance.

Correspondence should be addressed to Udo Bartsch, Department of Neurobiology, Swiss Federal Institute of Technology, Hönggerberg, 8093 Zürich, Switzerland.
}

Copyright (C) 1994 Society for Neuroscience $0270-6474 / 94 / 144756-13 \$ 05.00 / 0$ certain pathological conditions or after experimental manipulation (see, e.g., Büssow, 1978; Jung et al., 1978; Wyse, 1980; Wyse and Spira, 1981; Perry and Hayes, 1985; Berry et al., 1989; Perry and Lund, 1990), suggesting that the differential distribution of oligodendrocytes is not controlled by the axons themselves. Additionally, it has been shown that retinal cell cultures from rats never contain oligodendrocytes or oligodendrocyte progenitor cells, indicating that oligodendrocyte progenitor cells are unable to migrate into the retina (ffrench-Constant et al., 1988). Based on these observations, it has been concluded that the differential distribution of oligodendrocytes and myelin along retinal ganglion cell axons is due to a nonneuronal barrier at the retinal end of the optic nerve that prevents oligodendrocytes and/or their progenitor cells from entering the unmyclinated proximal part of the nerve and the retina (Hildebrand et al., 1985; ffrench-Constant et al., 1988; Perry and Lund, 1990). This non-neuronal barrier for myelinating glial cells has to be postulated not only for developing but also for adult optic nerves, since oligodendrocyte progenitor cells are present not only during development (Raff et al., 1983), but also in the adult (ffrench-Constant and Raff, 1986; Wolswijk and Noble, 1989). Oligodendrocyte progenitor cells isolated from adult nerves differ in several properties from their perinatal counterparts, including a different antigenic phenotype and morphology, a prolonged cell cycle time and differentiation rate, and a reduced migration rate (Wolswijk and Noble, 1989). However, they exhibit some common properties; for instance, they proliferate in response to platelet-derived growth factor (PDGF) in vitro and express the PDGF $\alpha$-receptor (Noble et al., 1988; Richardson et al., 1988; Hart et al., 1989; McKinnon et al., 1990; Wolswijk et al., 1991; Pringle et al., 1992). Progenitor cells in adult nerves represent a population of self-renewing stem cells that derive directly from oligodendrocyte progenitor cells present in developing optic nerves (Wren et al., 1992) and that have been implicated in the replacement of oligodendrocytes that are lost as a result of injury or naturally occurring cell death.

One possible molecule that might control the restricted distribution of neural cell types is the astrocyte-derived extracellular matrix (ECM) molecule tenascin (Prieto et al., 1990; Tsukamoto et al., 1991; S. Bartsch et al., 1992), which was discovered independently in several laboratories (Chiquet and Fambrough, 1984a,b; Erickson and Inglesias, 1984; Bourdon et al., 1985; Grumet et al., 1985; Kruse et al., 1985; reviewed by Erickson and Bourdon, 1989). Recent evidence indicates that tenascin is a multifunctional molecule involved in such different events as 
neuron-glia adhesion (Grumet et al., 1985; Kruse et al., 1985), elongation of neurites (Wehrle and Chiquet, 1990; Lochter et al., 1991; Husmann et al., 1992), repulsion of nerve cell bodies when offered as a choice with polyornithine (Faissner and Kruse, 1990), and divergence of growth cones when offered as a sharp substrate boundary (Taylor et al., 1993). With the help of recombinant tenascin fragments and a panel of monoclonal tenascin antibodies it has been shown that this multifunctionality is represented by several functionally distinct sites (Spring et al., 1989; Faissner and Kruse, 1990; Lochter et al., 1991; Husmann et al., 1992; Prieto et al., 1992; Taylor et al., 1993). Since tenascin appears to be critical for the migration of a variety of different cell types (Chuong et al., 1987; Tan et al., 1987; Bronner-Fraser, 1988; Halfter et al., 1989; Stern et al., 1989; Riou et al., 1990; Husmann et al., 1992) and since it reduces adhesion and spreading of cell bodies of different CNS nerve cell types (Faissner and Kruse, 1990; Lochter et al., 1991), neural crest cells (Tan et al., 1987; Epperlein et al., 1988; Mackie et al., 1988; Halfter et al., 1989), fibroblasts (Chiquet-Ehrismann et al., 1988), or mesodermal cells (Riou et al., 1990), we decided to study whether tenascin might control the distribution of oligodendrocytes and their progenitor cells along retinal ganglion cell axons. We thus analyzed the expression pattern of tenascin in the optic nerve of developing and adult mice by light and electron microscopic immunocytochemistry and by in situ hybridization. To study the spatiotemporal relationship between tenascin expression and migration of oligodendrocyte progenitor cells into the developing nerve, progenitor cells were visualized by in situ hybridization using a PDGF $\alpha$-receptor cRNA probe (Pringle et al., 1992; Mudhar et al., 1993). We then characterized the properties of tenascin as a substrate for the attachment of oligodendrocytes and their progenitor cells in vitro, using patterned substrates of tenascin and polyornithine.

\section{Materials and Methods}

Animals. Optic nerves with attached retina from neonatal 3-, 5-, 7-, $10-$ and 14-d-old and adult (i.e., more than $60 \mathrm{~d}$ old) C57BL/6J, ICR, or NMRI mice were used for immunocytochemistry and in situ hybridization. Immunocytochemistry was also performed on optic nerves with attached retina from 4-week-old rabbits. Cell cultures enriched in oligodendrocytes and their progenitors were prepared from brains of 1416-d-old NMRI mouse embryos taken from timed pregnancies with embryonic day 0 as the day a vaginal plug was found. All mice were bred at the departmental animal facilities. Rabbits were obtained from local breeders. Animals were killed by an overdose of chloral hydrate.

Antibodies. As primary antibodies for immunocy tochemistry, we used polyclonal rabbit antibodics to tenascin (Faissncr and Kruse, 1990), myelin-associated glycoprotein (Bartsch et al., 1989), laminin (Pesheva et al., 1989), fibronectin (Pesheva et al., 1989), monoclonal rat antibodies to tenascin (designated J1/tn2; Faissner and Kruse, 1990), and the monoclonal mouse antibodies $\mathrm{O} 1$ and $\mathrm{O} 4$ (Schachner et al., 1981 ; Sommer and Schachner, 1981). The monoclonal antibody M5 (Keilhauer et al., 1985) was used to eliminate neurons from cell cultures by immunocytolysis.

Primary antibodies for light microscopic immunocytochemistry were visualized by fluorescein isothiocyanate (FITC)-conjugated swine antirabbit (Dakopatts), goat anti-rat (Dianova), goat anti-mouse (Dynatech), tetramethylrhodamine isothiocyanate (TRITC)-conjugated swine antirabbit (Dakopatts) IgG antibodies, or peroxidase-conjugated protein A (Sigma). Primary antibodies for immunoelectron microscopy were detected using peroxidase-conjugated protein A. Visualization of digoxigenin-labeled cRNA probes for in situ hybridization was performed with alkaline phosphatase-conjugated Fab fragments to digoxigenin (Boehringer-Mannheim).

Plasmid vectors and preparation of digoxigenin-labeled $c R N A$ probes. Preparation of tenascin-specific digoxigenin-labeled cRNA probes and in vitro transcription in the presence of DIG-11-UTP were carried out as described previously (S. Bartsch et al., 1992). For generation of GFAPspecific cRNA probes, plasmid pBLGFAP was constructed by inserting a 1255 bp HindII fragment of plasmid Gl (Lewis et al., 1984), comprising the 5 ' part of the mouse GFAP cDNA sequence, into the HindIII site of pBluescript KS (Stratagene). Plasmid Gl was kindly provided by Dr. N. J. Cowan. GFAP antisense and sense probes were obtained by linearizing pBLGFAP with EcoRI and XhoI and subsequent in vitro transcription with T3 and T7-RNA polymerase, respectively. To generate MAG-specific cRNA probes, a 2044 bp ApaI fragment of vector p1B236-18 (Lai et al., 1987) coding for the cDNA sequence of mouse MAG was cloned into the HinclI site of pGEM2 (Promega), giving rise to plasmid pJ-GMP72. Vector p1B236-18 was kindly provided by Dr. C. Lai. MAG antisense and sense probes were obtained by linearizing plasmid pJ-GMP72 with HindIII and XbaI and subsequent in vitro transcription using SP6- and T7-RNA polymerase, respectively. Rat PDGF $\alpha$-receptor-specific sense and antisense cRNA probes were obtained by linearizing the pGEM-1 vector containing $1.5 \mathrm{~kb}$ of rat PDGF $\alpha$-receptor cDNA with HindIII and EcoRI and subsequent in vitro translation with T7- and SP6-RNA polymerase, respectively. This plasmid was kindly provided by Dr. W. Richardson. Prior to in situ hybridization GFAP, MAG, and PDGF $\alpha$-receptor cRNA probes were hydrolyzed as described (S. Bartsch et al., 1992) to an average fragment length of about 250 nucleotides.

Light microscopic immunocytochemistry. For light microscopic immunocytochemistry, longitudinal cryostat sections of fresh frozen optic nerves from adult mice (i.e., older than 2 months) and 4-week-old rabbits were prepared in the plane in which the nerve leaves the retina. The sections were mounted onto poly-L-lysine-coated coverslips and air dried. Sections were rinsed in phosphate-buffered saline (PBS), pH 7.6 , containing $0.1 \%$ bovine serum albumin (BSA) for $60 \mathrm{~min}$; incubated with primary antibodies for $2 \mathrm{hr}$, washed, incubated with FITC- or TRITC-conjugated secondary antibodies for $60 \mathrm{~min}$, washed again, and mounted onto slides, all at room temperature. Longitudinal sections of fresh frozen optic nerves with attached retina from developing mice were mounted onto 3-aminopropyltriethoxysilane (Sigma)-coated coverslips and fixed in PBS containing 4\% paraformaldehyde. Sections were washed in PBS, immersed in PBS/BSA, incubated with polyclonal tenascin antibodies, washed again, incubated with peroxidase-conjugated protein $\mathrm{A}$, and developed as described under Electron microscopic immunocytochemistry (see below). To visualize the cultured cells and the patterned substrates, cultures were double-immunolabeled with monoclonal mouse antibody $\mathrm{Ol}$ or $\mathrm{O} 4$ and polyclonal rabbit antibodies recognizing the different ECM molecules coated. For this, cultures were rinsed in $\mathrm{PBS} / \mathrm{BSA}$ for $30 \mathrm{~min}$, incubated with antibodies recognizing cell type-specific antigens and antibodies recognizing the coated ECM molecules for $2 \mathrm{hr}$, washed, incubated with the corresponding FITC- or TRITC-conjugated secondary antibodies, washed again, and mounted onto slides. To identify $\mathrm{O} 4$-positive but $\mathrm{Ol}$-negative glial progenitor cells, cultures were first incubated with the $\mathrm{Ol}$ antibody, followed by a TRITC-conjugated secondary antibody. Then cultures were incubated with the $\mathrm{O} 4$ antibody, followed by a FITC-conjugated secondary antibody. As a control, incubation of sections or cultures with primary antibodies was omitted and no staining was visible (data not shown).

Electron microscopic immunocytochemistry. Indirect immunoelectron microscopy was carried out as described in detail elsewhere (Bartsch et al., 1990). Briefly, the eyes and the proximal part of the optic nerve from adult mice were immersion fixed in $0.12 \mathrm{M}$ Palay buffer (Palay and Chan-Palay, 1974), pH 7.3, containing $4 \%$ paraformaldehyde at $4^{\circ} \mathrm{C}$. Vibratome sections prepared from the unmyelinated proximal part of the optic nerve were immersed in $0.1 \%$ BSA in PBS (pH 7.6) for several hours, followed by $0.1 \mathrm{M} \mathrm{NaIO}_{3}(10 \mathrm{~min}), 1 \% \mathrm{NaBH}_{4}(15 \mathrm{~min})$, and $20 \%$ dimethyl sulfoxide $(30 \mathrm{~min})$. After washing, sections were incubated with polyclonal tenascin antibodies overnight at room temperature, washed again, and incubated with horseradish peroxidaseconjugated protein A (Sigma). After fixation with $0.1 \%$ glutaraldehyde in Palay buffer, vibratome sections were immersed in $0.02 \%, 3,3^{\prime}$-diaminobenzidine $4 \mathrm{HCl}(\mathrm{DAB})$ in $0.04 \mathrm{M}$ Tris buffer, $\mathrm{pH} 7.6$, for at least 30 min. Sections were then immersed in the same DAB solution containing $0.01 \% \mathrm{H}_{2} \mathrm{O}_{2}$ for up to $60 \mathrm{~min}$ and postfixed in $2 \% \mathrm{OsO}_{4}$. Ultrathin sections were examined with a Zeiss EM $10 \mathrm{C}$.

In situ hybridization. In situ hybridization was carried out as described in detail elsewhere (S. Bartsch et al., 1992). In brief, longitudinal cryostat sections, $14 \mu \mathrm{m}$ in thickness, were prepared from fresh-frozen mouse optic nerves in the plane in which the optic nerve leaves the retina. Sections were mounted onto 3-aminopropyltriethoxysilane (Sigma)- 

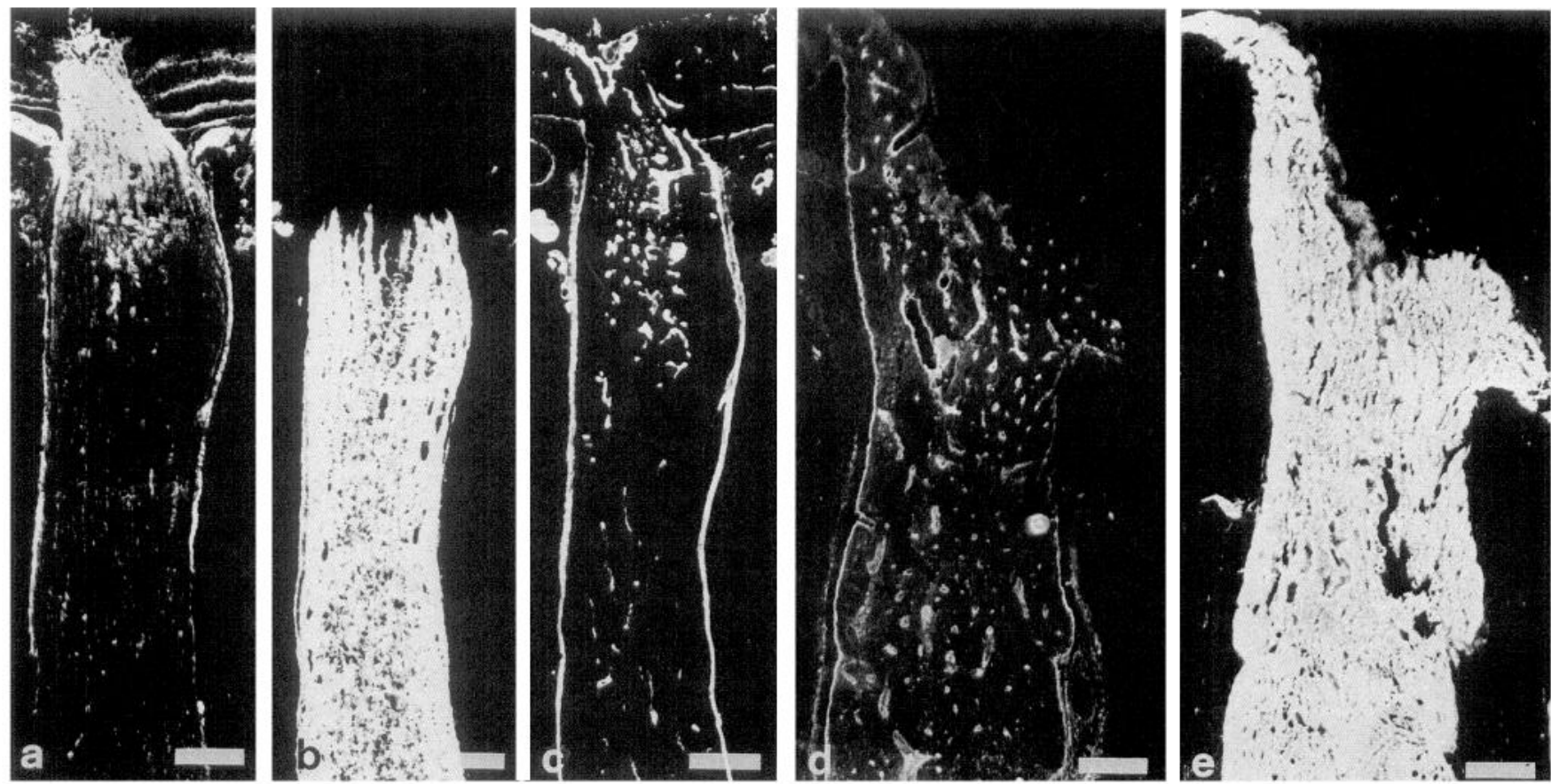

Figure 1. Indirect immunofluorescence localization of tenascin $(a, d)$, MAG $(b, e)$, and laminin $(c)$ in three consecutive longitudinal sections of an adult mouse optic nerve $(a-c)$ and two consecutive longitudinal sections of a 4-week-old rabbit optic nerve $(d, e)$. In the mouse, increased tenascin immunoreactivity is detectable in the unmyelinated proximal part of the optic nerve $(a)$, while the MAG-immunoreactive myelinated part of the optic nerve $(b)$ is almost completely tenascin negative $(a)$. Blood vessels located in the unmyelinated proximal part of the nerve and the partly myelinated transition zone to the myelinated distal part of the optic nerve are labeled by tenascin antibodies $(a)$. Laminin-immunoreactive blood vessels of the myelinated optic nerve, in contrast, show no significant tenascin immunoreactivity (compare $a$ and $c$ ). In the rabbit, MAG immunoreactivity is detectable not only in the optic nerve but also in the retinal nerve fiber layer (e), since a subpopulation of retinal ganglion cell axons is also myelinated intraretinally. Note the lack of an increased tenascin immunoreactivity at the retinal end of the nerve in this species $(d)$. Scale bars: $a-c, 150 \mu \mathrm{m} ; d$ and $e, 250 \mu \mathrm{m}$.

coated coverslips and were immediately fixed in PBS (pH 7.6) containing $4 \%$ paraformaldehyde. Prehybridization of sections was performed overnight at $37^{\circ} \mathrm{C}$ with a prehybridization buffer containing $50 \%$ formamide, $25 \mathrm{~mm}$ EDTA, $50 \mathrm{~mm}$ Tris $\cdot \mathrm{HCl}(\mathrm{pH} 7.6), 2.5 \times$ Denhardt's solution, $0.25 \mathrm{mg} / \mathrm{ml}$ tRNA (Boehringer-Mannheim), and $20 \mathrm{~mm} \mathrm{NaCl}$. Hybridization was carried out at $55^{\circ} \mathrm{C}$ for $12-20 \mathrm{hr}$ with $50 \%$ formamide, $20 \mathrm{~mm}$ Tris $\cdot \mathrm{HCl}(\mathrm{pH} 7.5), 1 \mathrm{~mm}$ EDTA, $1 \times$ Denhardt's solution, $0.5 \mathrm{mg} / \mathrm{ml}$ tRNA, $0.1 \mathrm{mg} / \mathrm{ml}$ polyA RNA (Sigma), $0.1 \mathrm{M}$ dithiothreitol (Sigma), 10\% dextran sulfate (Sigma), and the corresponding antisense or sense cRNA probes. Digoxigenin-labeled probes were visualized using alkaline phosphatase-conjugated Fab fragments to digoxigenin (Boehringer-Mannheim). The specificity of the hybridization signal was confirmed in every experiment by hybridizing sections with the corresponding sense $\mathrm{cRNA}$ probes.

Quantitative analysis. To analyze the spatiotemporal relation between the tenascin gradient at the retinal end of the nerve and immigrating oligodendrocyte progenitor cells during development, we hybridized optic nerve sections from neonatal, 3-, 5-, and 7-d-old mice with the tenascin cRNA probe and visualized oligodendrocyte progenitor cells with a PDGF $\alpha$-receptor cRNA probe (Pringle et al., 1992). The distance between the inner limiting membrane of the retina at the optic nerve head and the distal end of the tenascin gradient or the most proximally and clearly labeled PDGF $\alpha$-receptor-positive cell was measured at a final magnification of $125 \times$ with the help of an ocular grid. At least 60 sections from three representative experiments were analyzed for each developmental age and cRNA probe. Only those sections in which the optic nerve was cut in the plane where it leaves the eye were included in the analysis.

Cell culture. Single-cell suspensions enriched in oligodendrocytes and their progenitor cells were prepared from the brains of 14-16-d-old NMRI mouse embryos (Trotter et al., 1989). In brief, cells from embryonic mouse brains were plated into poly-L-lysine-coated tissue culture flasks and maintained in Eagle's basal medium (BME) containing $10 \%$ horse serum (HS). Neurons were eliminated after $4-5 \mathrm{~d}$ in vitro by immunocytolysis using the monoclonal antibody M5 (Keilhauer et al.,
$1985)$ and guinea pig complement. Macrophages were removed after gently shaking the flasks after an additional culture period of 8-10 d and changing the medium. Oligodendrocytes and their progenitor cells present in the top layer of adherent cells were then separated from underlying cells by shaking the flasks vigorously for approximately 15 sec. Shaken-off cells were replated and maintained for $1 \mathrm{~d}$ in BME containing 10\% HS and then in modified Sato medium [Dulbecco's modified Eagle's medium containing $0.2 \%(\mathrm{w} / \mathrm{v})$ sodium bicarbonate, $0.01 \mathrm{mg} / \mathrm{ml}$ insulin, $0.1 \mathrm{mg} / \mathrm{ml}$ transferrin, $2 \mathrm{~mm}$ glutamine, $200 \mathrm{~nm}$ progesterone, $100 \mu \mathrm{M}$ putrescine, $220 \mathrm{~nm}$ sodium selenite, $400 \mathrm{~nm}$ triiodothyronine, $500 \mathrm{~nm}$ thyroxine, and $0.025 \mathrm{mg} / \mathrm{ml}$ gentamicin sulfate]. The purity of oligodendrocytes and their progenitor cells was at least $95 \%$ (Trotter et al., 1989). Cells were plated on glass coverslips (16 mm in diameter) coated with patterned substrates of different ECM molecules (see next paragraph) and maintained for $1-2 \mathrm{~d}$ in modified Sato medium.

Coating of coverslips with extracellular matrix molecules. Patterned substrates were prepared by first incubating coverslips in $0.1 \mathrm{M}$ borate buffer, $\mathrm{pH} 8.2$, containing poly-DL-ornithine (Sigma) for up to $2 \mathrm{hr}$, washing with distilled water, drying, and incubating overnight with PBS, pH 7.6, containing $50 \mu \mathrm{g} / \mathrm{ml}$ tenascin purified from mouse brain (Faissner and Kruse, 1990), and fibronectin or laminin (Boehringer-Mannheim and Bethesda Research Laboratories, respectively). Coverslips were then washed with Hank's balanced salt solution and patterned substrates were prepared by scraping the surface of the coverslip with the tip of an Eppendorf pipette.

\section{Results}

Immunocytochemical light and electron microscopic analysis of tenascin expression in the optic nerve of developing and adult mice

Longitudinal, consecutive sections of adult mouse optic nerves were stained by indirect immunofluorescence with polyclonal 

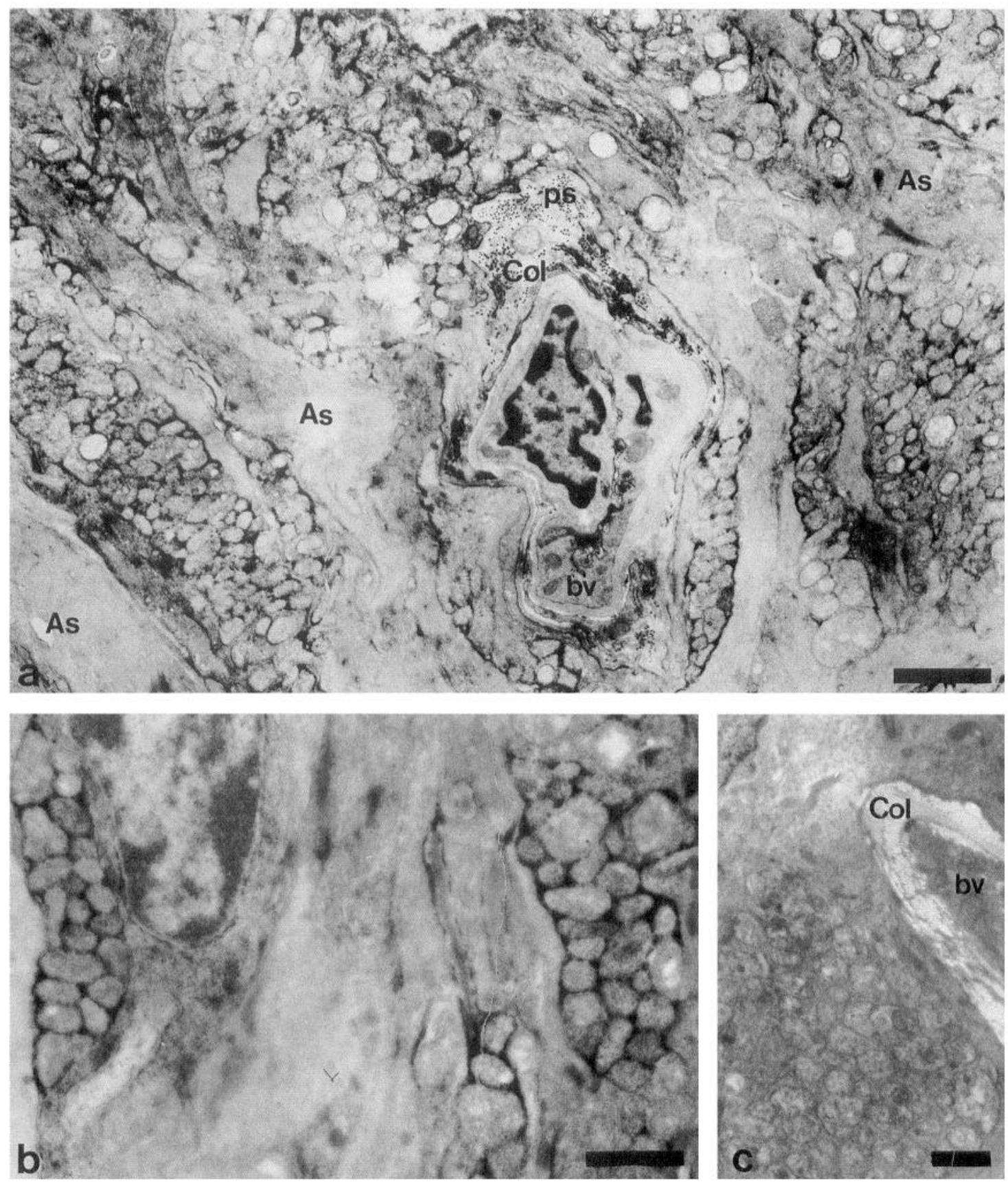

Figure 2. Immunoelectron microscopic localization of tenascin in the unmyelinated proximal part of an adult mouse optic nerve using polyclonal antibodies $(a, b)$. Tenascin immunoreactivity is associated with the cell surface of astrocytes $(A s)$ and unmyelinated retinal ganglion cell axons. In addition, collagen fibrils $(\mathrm{Col})$, located in the perivascular spaces $(p s)$ of the anatomically specialized blood vessels $(b v)$ in this region of the nerve are immunolabeled $(a)$. As a control, incubation with primary antibodies was omitted and no labeling was visible $(c)$. Scale bars: $a, 2 \mu \mathrm{m} ; b$ and $c, 1 \mu \mathrm{m}$.

antibodies to tenascin, myelin-associated glycoprotein (MAG), and laminin (Fig. $1 a-c$ ). Increased tenascin immunoreactivity was detectable in the most proximal, unmyelinated part of the optic nerve, whereas the myelinated optic nerve was only weakly immunostained (Fig. 1 $a$; for the distribution of myelin see Fig. $1 b$ ). Highest tenascin immunoreactivity was found at the entry region of the nerve into the retina with decreasing intensity toward the myelinated part of the optic nerve. Moreover, the large and anatomically specialized blood vessels of the unmyelinated proximal part of the nerve (see below; Hildebrand et al., 1985), but not blood vessels of the myelinated part of the optic nerve, showed strong tenascin immunoreactivity (compare Fig. 1, $a$ and $c$; see also U. Bartsch et al., 1992). In the rabbit, MAG immunoreactivity was not restricted to distal regions of the optic nerve but was also detectable in the retinal nerve fiber layer (Fig. 1e), consistent with the fact that in this species a subpopulation of retinal ganglion cell axons is also myelinated intraretinally (Berliner, 1931; Schnitzer, 1985). In contrast to the mouse, however, no differential distribution of tenascin was detectable at the retinal end of the nerve using the monoclonal tenascin antibody $\mathrm{J} 1 / \operatorname{tn} 2$ (Fig. $1 d$ ).

The localization of tenascin in the unmyelinated, proximal 

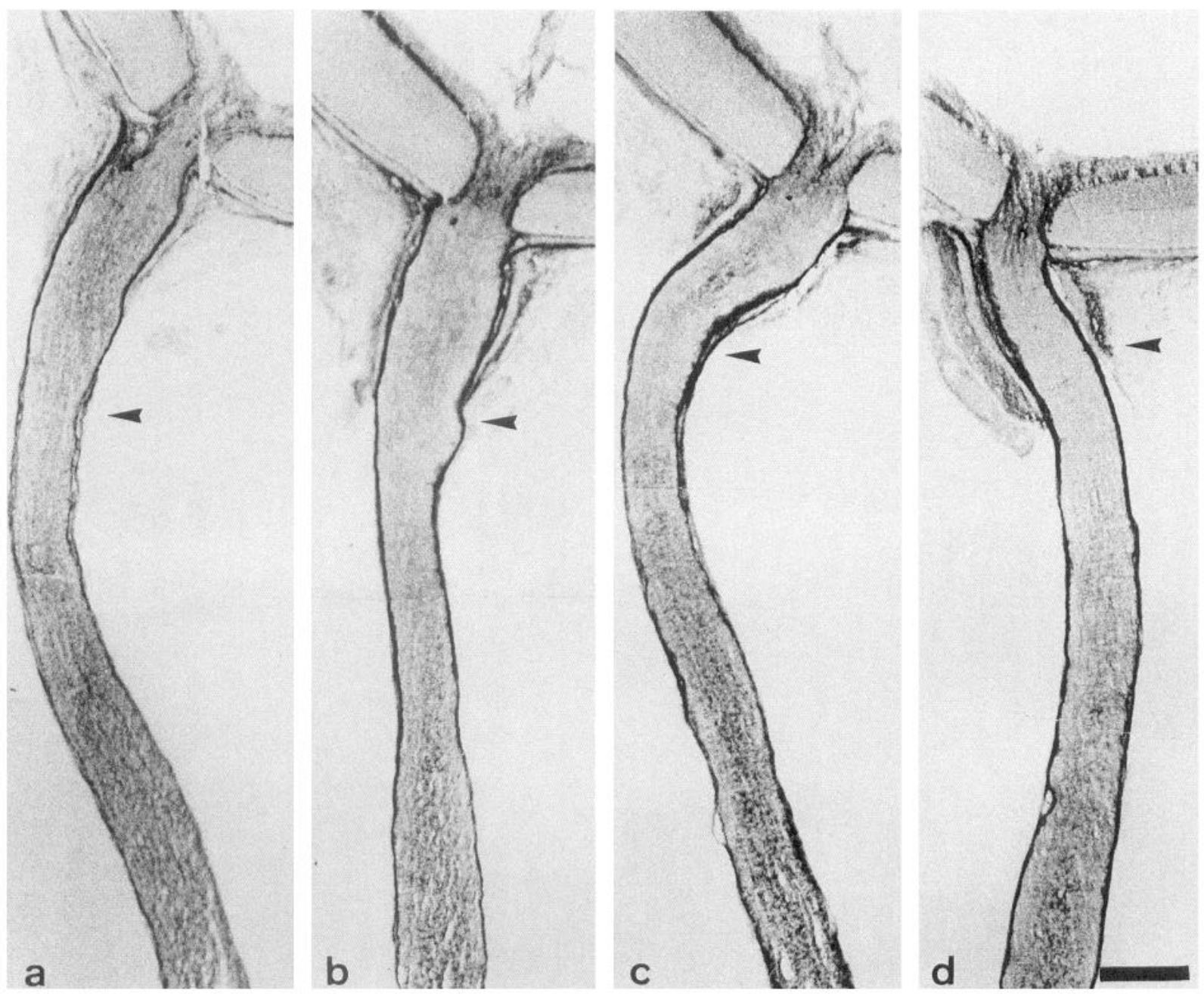

Figure 3. Light microscopic localization of tenascin protein in longitudinal sections of optic nerves from neonatal $(a), 3(b)$-, $5(c)$-, and $7(d)$-dold mouse optic nerves. An accumulation of tenascin protein at the retinal end of the optic nerve is already detectable in neonatal animals $(a)$. More distally, intensity of tenascin immunoreactivity decreases, but increases again toward the chiasmal end of the nerve. This differential distribution of tenascin along the nerve is more clearly visible in older animals $(b-d)$. Arrowheads indicate the regions with weakest immunoreactivity. Scale bar, $200 \mu \mathrm{m}$

part of the optic nerve was further analyzed at the ultrastructural level. All retinal ganglion cell axons in this region of the adult nerve were unmyelinated and embedded in a dense network of astrocytic processes, either as single axons or as small axon fascicles (Fig. 2a,b). Astrocytes and astrocytic processes were packed with intermediate glial filaments (Fig. $2 a$ ) and were more numerous in this part of the nerve than in more distal and myelinated regions (data not shown). Tenascin immunoreactivity was detectable in association with cell surfaces of astrocytes and unmyelinated retinal ganglion cell axons (Fig. 2a,b). Blood vessels in this region of the nerve are surrounded by large perivascular spaces (Hildebrand et al., 1985) that were filled with tenascin-immunoreactive collagen fibrils (Fig. $2 a$ ).

To analyze the distribution of tenascin at the retinal end of the nerve during development, longitudinal sections of optic nerves from different developmental ages were incubated with polyclonal tenascin antibodies that were visualized using peroxidase-conjugated protein A (Fig. $3 a-d$ ). A preferential accumulation of tenascin at the retinal end of the nerve was already detectable in neonatal animals (Fig. $3 a$ ). A gradient of tenascin immunoreactivity at the retinal end of the nerve became more apparent in 3-d-old (Fig. 3b) animals and was clearly visible in 5 (Fig. 3c)- and 7 (Fig. 3d)-d-old mice. At all developmental ages, tenascin immunoreactivity was weak distal to this tenascin accumulation, but increased again toward the chiasmal end of the nerve (Fig. $3 a-d$ ). This differential distribution of tenascin protein along developing mouse optic nerves was similar to the differential distribution of tenascin mRNA (see below). As a control, incubation of sections with primary antibodies was omitted and no labeling was detectable (data not shown).

\section{Localization of tenascin-, GFAP-, and MAG-MRNA in the adult optic nerve}

Since tenascin is a secreted glycoprotein (Kruse et al., 1985; S. Bartsch et al., 1992; U. Bartsch et al., 1992), in situ hybridization using a digoxigenin-labeled cRNA probe was performed to determine the location of cells producing tenascin (Fig. 4a). Longitudinal sections from the same optic nerve were also analyzed using cRNA probes specific for mouse glial fibrillary acidic protein (GFAP) to visualize astrocytes (Fig. $4 b$ ) and MAG to visualize oligodendrocytes (Fig. $4 \mathrm{c}$ ).

Cells containing tenascin transcripts were not visible in the 

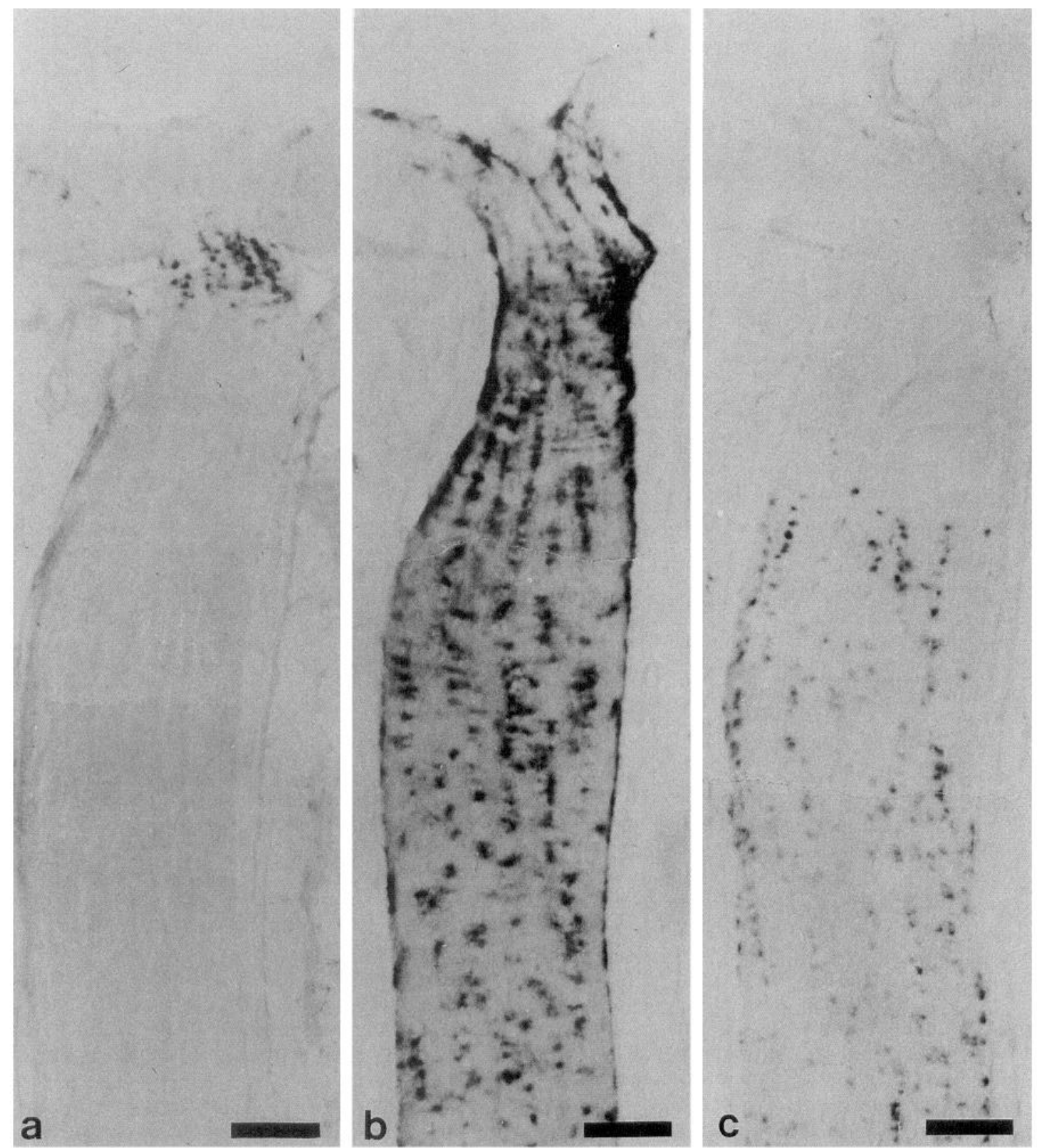

Figure 4. Localization of tenascin (a), GFAP $(b)$, and MAG $(c)$ mRNA in longitudinal cryostat sections prepared from the same adult mouse optic nerve using the corresponding digoxigenin-labeled antisense cRNA probes. Cells containing tenascin transcripts are located in a narrow zone of the unmyelinated proximal part of the nerve at its entry zone into the retina $(a)$. GFAP-positive astrocytes are detectable along the entire length of retinal ganglion cell axons and are usually aligned in longitudinally oriented rows of cells $(b)$. In the unmyelinated part of the nerve, astrocytes are present in higher densities and are labeled more intensely than in the myelinated part of the optic nerve $(b$; for the distribution of oligodendrocytes, see $c$ ). MAG-positive oligodendrocytes are restricted to the myelinated distal regions of the optic nerve but are absent from the most proximal part and from the retina $(c)$. Similar to astrocytes $(b)$, oligodendrocytes tend to align in longitudinally oriented rows of cells $(c)$. Scale bars, $100 \mu \mathrm{m}$.

myelinated part of the optic nerve of adult animals (Fig. 4a). Only a population of cells located in the unmyelinated proximal part of the nerve at its entry zone into the retina was labeled by the tenascin cRNA probe. These cells were usually aligned in longitudinal rows (Fig. $4 a$ ). This distribution of tenascin mRNA thus confirms the accumulation of tenascin protein at the retinal end of the nerve (see Fig. 1a). However, not all cells located in the unmyelinated proximal part of the optic nerve contained detectable levels of tenascin transcripts. Usually, the distal region of the unmyelinated part of the nerve was devoid of positive cells (compare Fig. $4 a$ for the distribution of cells expressing tenascin transcripts and Fig. $4 c$ for the distribution of oligodendrocytes expressing MAG transcripts). Similar results were obtained in experiments in which sections had first been hybridized with the tenascin cRNA probe and subsequently stained with polyclonal MAG antibodies to visualize the distribution of myelin (data not shown). Only occasionally, we found a few, weakly tenascin-positive cells in distal regions of the unmyelinated proximal part of the nerve. These observations exclude the possibility that cells along the entire length of the optic nerve express 

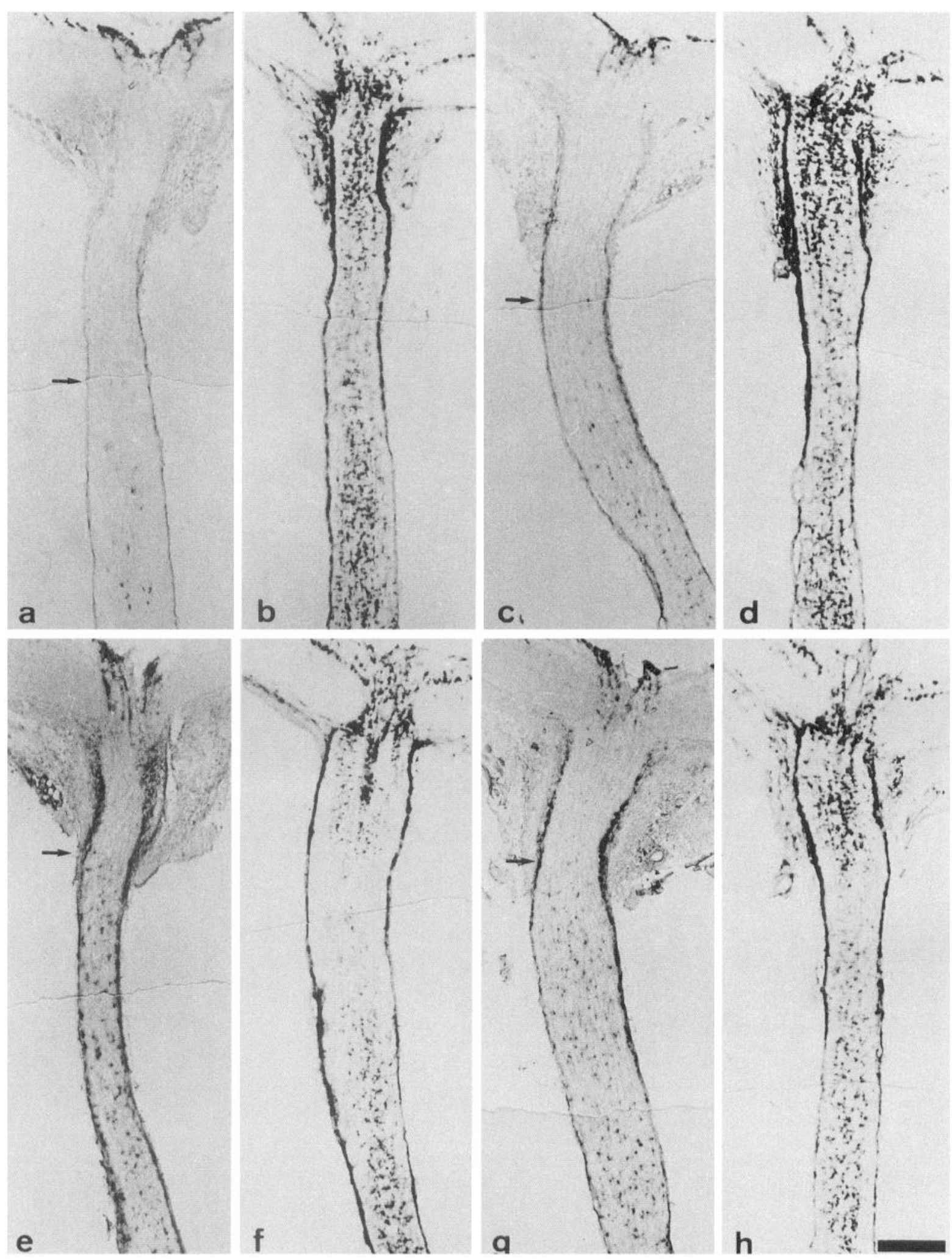

Figure 5. Distribution of PDGF $\alpha$-receptor mRNA $(a, c, e, g)$ and tenascin mRNA $(b, d, f, h)$ in longitudinal sections of optic nerves from neonatal $(a, b), 3(c, d)-, 5(e, f)$-, and $7(g, h)$-d-old mice. At all developmental ages, a high density of cells containing tenascin transcripts is present at the retinal end of the nerve $(b, d, f, h)$. Distal to this gradient, the density of labeled cells decreases significantly and then increases again toward the chiasmal end of the nerve. In neonatal animals, only a few cells are labeled with the PDGF $\alpha$-receptor cRNA probe (a). With increasing age, PDGF $\alpha$-receptor-positive cells become more numerous $(c, e, g)$. Note that the distance between the retina and the most proximally located PDGF $\alpha$-receptor-positive cell (arrows in $a, c, e, g$ ) decreases significantly during the first postnatal week. Scale bar, $200 \mu \mathrm{m}$. 

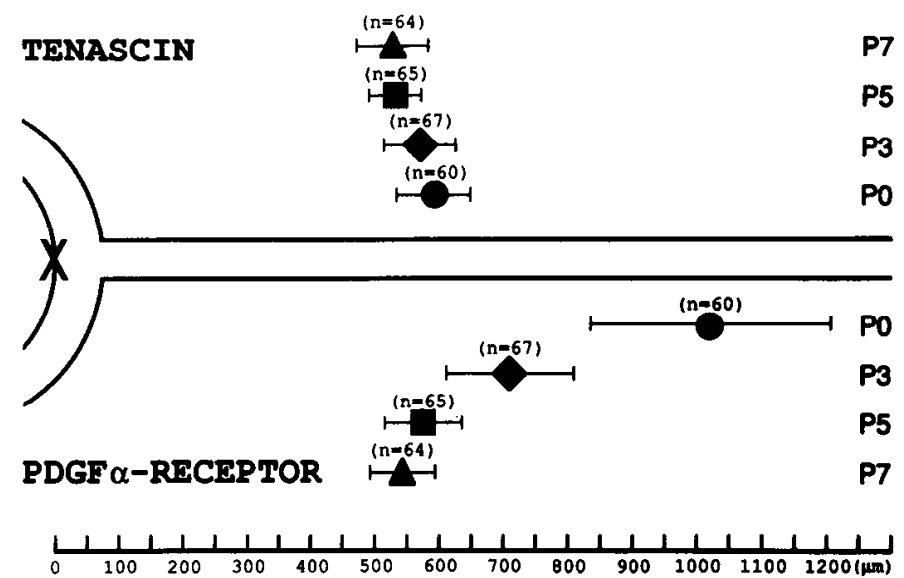

Figure 6. Schematic presentation of the spatiotemporal relationship between the distribution of tenascin mRNA and PDGF $\alpha$-receptor mRNA in the developing mouse optic nerve. Values indicate the distance between the inner limiting membrane of the retina at the optic nerve head $(x)$ and the distal end of the gradient of cells expressing tenascin mRNA at the retinal end of the optic nerve or the most proximally located PDGF $\alpha$-receptor-positive cell. Sections from 7 (triangles)-, 5 (squares)-, and 3 (diamonds)-d-old and neonatal (circles) animals were analyzed. In 5- and 7-d-old animals, PDGF $\alpha$-receptor-positive cells are located at the distal end of the tenascin gradient. In 3-d-old and, in particular, in neonatal animals, PDGF $\alpha$-receptor-positive cells are located more distally and have not yet reached the tenascin gradient. Mean values and standard deviations from three independent experiments are shown. The total number of sections analyzed for each developmental age and cRNA probe is indicated in parentheses.

similar amounts of tenascin but that only cells located in the unmyelinated part of the nerve are visualized by our in situ hybridization method because unmyelinated tissue is more easily penetrated by cRNA probes or antibudies. Sections that were hybridized with the GFAP cRNA probe showed an increased density of labeled cells in the unmyelinated and partly myelinated proximal part of the optic nerve when compared to more distal and fully myelinated regions (compare Fig. $4 b$ for the distribution of astrocytes and Fig. $4 c$ for the distribution of oligodendrocytes). In addition, the intensity of the hybridization signal in individual cells was higher in the unmyelinated and partly unmyelinated part than in the fully myelinated part of the optic nerve (Fig. $4 b$ ). Astrocytes in the unmyelinated as well as in the myelinated part of the nerve appeared to align in longitudinally oriented rows (Fig. $4 b$ ). Labeled cells in sections hybridized with the MAG cRNA probe were restricted to the myelinated part of the nerve and were absent from the most proximal part of the nerve and from the retina (Fig. $4 c$ ). Similar to GFAP-positive astrocytes, MAG-positive oligodendrocytes tended to align preferentially in longitudinally oriented rows of cells (Fig. 4c). No labeled cells were detectable in control sections that were hybridized with the corresponding sense cRNA probes (data not shown).

\section{Localization of tenascin-and PDGF- $\alpha$-receptor $m R N A$ in the developing optic nerve}

Cells expressing tenascin were detectable along the entire length of the optic nerve of neonatal animals (Fig. $5 b$; see also $\mathrm{U}$. Bartsch et al., 1992). However, the density of labeled cells and the intensity of the hybridization signal were increased at the retinal end of the nerve when compared with the adjacent distal region (Fig. 5b). Cells at the retinal end of the optic nerve con-
Table 1. The spatiotemporal relationship between the distribution of tenascin mRNA and PDGF $\alpha$-receptor mRNA in developing mouse optic nerves

\begin{tabular}{llc} 
Age & Tenascin & PDGF $\alpha$-receptor \\
\hline P0 & $591 \pm 52 \mu(n=60)$ & $1019+185 \mu \mathrm{m}(n=60)$ \\
P3 & $569 \pm 55 \mu \mathrm{m}(n=67)$ & $710 \pm 101 \mu \mathrm{m}(n=67)$ \\
P5 & $528 \pm 40 \mu \mathrm{m}(n=65)$ & $575 \pm 62 \mu \mathrm{m}(n=65)$ \\
P7 & $526 \pm 56 \mu \mathrm{m}(n=64)$ & $544 \pm 52 \mu \mathrm{m}(n=64)$ \\
\hline
\end{tabular}

Values indicate the distance between the inner limiting membrane of the retina at the optic nerve head and the distal end of the retinal tenascin gradient or the most proximally located PDGF $\alpha$-receptor-positive cell. Mean values \pm standard deviation from three independent experiments are shown. The total number of sections analyzed for each developmental age $(P=$ postnatal day) and cRNA probe is indicated in parentheses.

tinued to be strongly labeled by the tenascin cRNA probe in 3 (Fig. 5d)-, 5 (Fig. 5f)-, and 7 (Fig. 5h)-d-old mice. The intensity of the hybridization signal and the number of labeled cells in more distal regions of the nerve gradually decreased with increasing age. This was particularly evident in the region of the nerve directly adjacent to the tenascin gradient (Fig. $5 d, f, h$ ). The labeling intensity in the distal part of the optic nerve further decreased in 10-d-old animals, and cells containing tenascin transcripts were almost absent in the myelinated segment of the nerve of 14-d-old animals (data not shown). Thus, the distribution of tenascin mRNA in developing mouse optic nerves confirms our observations at the protein level (see Fig. 3).

Only a few PDGF $\alpha$-receptor-positive cells were detectable in optic nerves of neonatal animals (Fig. 5a). Labeled cells were not detectable in proximal regions of the nerve, but were restricted to distal regions, with an increasing density toward the optic chiasm (Fig. 5a). In 3-d-old animals, the number of cells containing PDGF $\alpha$-receptor mRNA increased and, more importantly, labeled cells became detectable in more proximal regions of the nerve when compared with neonatal animals (compare Fig. 5, $a$ and $c$ ). The density of labeled cells further increased and the distance between the retina and the most proximally located PDGF $\alpha$-receptor-positive cells further decreased in 5 (Fig. 5e)- and 7 (Fig. $5 g$ )-d-old mice. At these developmental ages, PDGF $\alpha$-receptor-positive cells appeared to have reached the distal end of the tenascin gradient at the retinal end of the nerve (compare Fig. $5 e, f$ and Fig. $5 g, h$ ). At all developmental ages analyzed, labeling with the PDGF $\alpha$-receptor probe was also visible in the meninges, in the optic nerve head, and at the inner aspect of the retina (i.e., at the optic fiber layer; Fig. 5a,c,e,g, see also Pringle et al., 1992; Mudhar et al., 1993). Sections hybridized with tenascin- or PDGF $\alpha$-receptor sense cRNA probes were unlabeled at all developmental ages analyzed (data not shown).

To quantify the spatiotemporal relationship between the gradient of cells containing tenascin mRNA at the retinal end of the optic nerve and cells containing PDGF $\alpha$-receptor mRNA, we measured the distance between the inner limiting membrane of the retina at the optic nerve head and the end of the tenascin gradient or the most proximally located PDGF $\alpha$-receptor-positive cell (Fig. 6, Table 1). At least 60 sections from three independent experiments for each developmental age (P0, P3, P5, and P7) and cRNA probe wcrc analyzed. The distance between the inner limiting membrane of the retina at the optic nerve head and the end of the tenascin gradient was similar for all developmental ages (approximately $550 \mu \mathrm{m}$; Fig. 6, Table 1). 

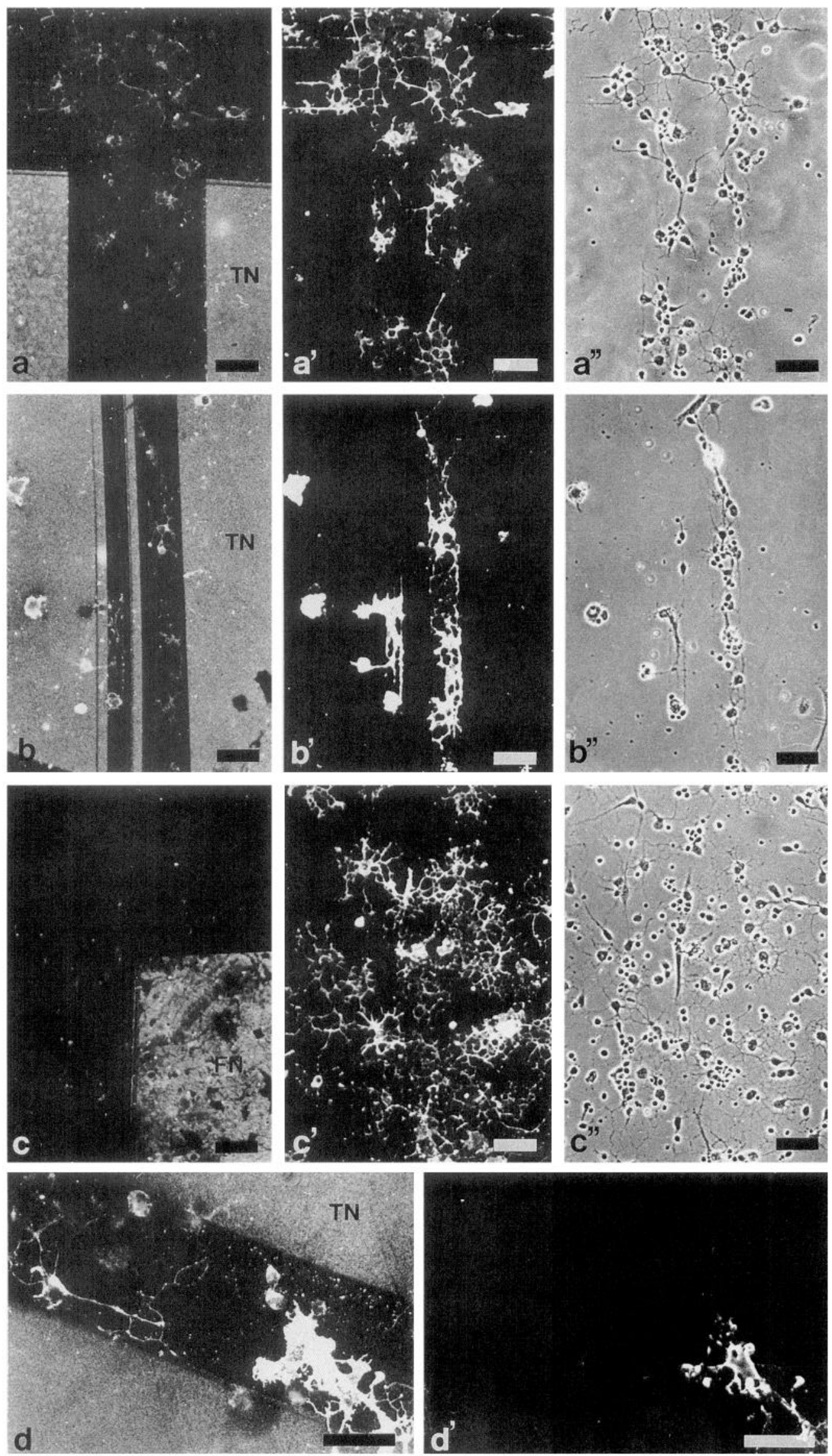
The distance between the inner limiting membrane of the retina at the optic nerve head and the most proximally located PDGF $\alpha$-receptor-positive cell, however, changed significantly with increasing age (Fig. 6, Table 1). In 5- and 7-d-old mice, the most proximally located cells were visible at the distal end of the tenascin gradient (Fig. 6, Table 1). In 3-d-old and, in particular, in neonatal animals, PDGF $\alpha$-receptor-positive cells were located more distally when compared with older animals (710 \pm $101 \mu \mathrm{m}$ for 3-d-old and $1019 \pm 185 \mu \mathrm{m}$ for neonatal mice) and thus had not yet reached the distal end of the tenascin gradient (569 $\pm 55 \mu \mathrm{m}$ for 3 -d-old and $591 \pm 52 \mu \mathrm{m}$ for neonatal animals; Fig. 6, Table 1).

\section{Distribution of oligodendrocytes and their progenitor cells on patterned substrates of different ECM molecules}

To analyze the substrate properties of tenascin for oligodendrocytes and their progenitor cells, we plated single-cell suspensions, enriched in these cell types, on patterned substrates of tenascin and polyornithine. As a control, cells were plated on patterned substrates of two other ECM molecules, fibronectin and laminin. After a culture period of $1-2 \mathrm{~d}$, the distribution of cells on the patterned substrates was analyzed by indirect immunofluorescence using the monoclonal $\mathrm{O} 4$ and $\mathrm{O} 1$ antibodies, which allow the distinction of oligodendrocytes and their direct progenitor cells, respectively (Trotter and Schachner, 1989). Double immunofluorescence using O4 or O1 antibody and antibodies to the different ECM molecules allowed the visualization of cultured cells and the patterned substrate, respectively (Fig. 7). Most of the 04-immunoreactive cells, including progenitor cells that were $\mathrm{O} 4$ positive but $\mathrm{O} 1$ negative and showed an immature morphology (Trotter and Schachner, 1989), avoided the tenascin substrate and preferred polyornithine (Fig. $7 a, b, d$ ). Patterned laminin/polyornithine (data not shown) or fibronectin/polyornithine (Fig. 7c) substrates had no significant influence on the distribution of the O4-positive cells. Furthermore, GFAP-immunoreactive astrocytes did not avoid tenascin on patterned tenascin/polyornithine substrates under experimental conditions similar to those used in this study (Faissner and Kruse, 1990).

\section{Discussion}

In rats and mice, virtually all retinal ganglion cell axons become myelinated in the distal (i.e., chiasmal) part of the optic nerve, but remain myelin-free in their intraretinal part and in the most proximal (i.e., retinal) region of the nerve (Sugimoto et al., 1984; Hildebrand et al., 1985; Bartsch et al., 1989; Perry and Lund, 1990). Under certain pathological or experimental conditions, however, the proximal segment of retinal ganglion cell axons becomes myelinated by Schwann cells or oligodendrocytes, indicating that retinal ganglion cell axons are, in principle, myelination-competent along their entire length (for references, see introductory remarks). Based mainly on these observations, it has been postulated that the differential distribution of myelin and myelin-forming glial cells along retinal ganglion cell axons is not controlled by the axons themselves but by non-neuronal factors. Astrocytes in the unmyelinated proximal part of the optic nerve and serum-derived components, which can penetrate this region as a consequence of a locally deficient bloodbrain barrier (Tso et al., 1975; Flage, 1977) and which might influence the differentiation of oligodendrocyte progenitor cells, have been discussed in this context (Hildebrand et al., 1985; ffrench-Constant et al., 1988; Perry and Lund, 1990). Importantly, non-neuronal factors have to prevent the migration of oligodendrocytes or oligodendrocyte progenitor cells into the unmyelinated proximal part of the optic nerve and into the retina not only during development but also in the adult, since motile oligodendrocyte progenitor cells persist in optic nerves of adult animals (ffrench-Constant and Raff, 1986; Wolswijk and Noble, 1989). Thus, the optic nerve provides a system that allows the analysis of factors leading to a restricted distribution of a distinct macroglial cell type during development and maintaining this distribution in the adult.

In adult mice, increased tenascin immunoreactivity is restricted to the unmyelinated, most proximal part of the optic nerve. Highest tenascin immunoreactivity was always found at the entry zone of the nerve into the retina, consistent with the observation that cells containing tenascin transcripts are restricted to this region. However, the distribution of tenascin mRNA is more restricted than that of tenascin protein. It is reasonable to assume that the final distribution of a secreted molecule is determined by the location of its receptor(s). Since astrocytes represent the predominant cell type in the unmyelinated proximal segment of the nerve (Hildebrand et al., 1985; Skoff et al., 1986), we hypothesize that cells expressing tenascin represent a distinct subpopulation of optic nerve astrocytes. This interpretation is in agreement with previous studies demonstrating that tenascin in the CNS is glia derived (Prieto et al., 1990; Tsukamoto et al., 1991; Tucker and McKay, 1991; S. Bartsch et al., 1992; U. Bartsch et al., 1992; Laywell et al., 1992). The possibility that tenascin-positive cells in the proximal region of the adult nerve are astrocytes is also indicated by the observation that the distribution of tenascin- and GFAP-positive cells is very similar, both being arranged in longitudinally oriented rows of cells (Skoff et al., 1986).

In developing nerves, cells expressing levels of tenascin mRNA that are higher at the retinal end of the nerve than in the adjacent more distal region can be distinguished already in neonatal animals. At this age, an accumulation of tenascin at the retinal end of the nerve is also detectable at the protein level and becomes more clearly visible in older animals. In general, the distribution of tenascin protein resembles the distribution of tenascin mRNA at all developmental ages analyzed. To relate the gradient of tenascin-expressing cells to the location of im-

\footnotetext{
Figure 7. Determination of the attachment of oligodendrocytes and/or oligodendrocyte progenitor cells on patterned substrates of tenascin (TN) and polyornithine $(a, b, d)$ or fibronectin $(F N)$ and polyornithine $(c)$. The distribution of the substrates is visualized by indirect immunofluorescence using polyclonal antibodies to tenascin $(a, b, d)$ or fibronectin $(c)$. The distribution of O4-positive cells on the patterned substrates is shown by indirect in!munofluorescence in $a^{\prime}, b^{\prime}, c^{\prime}$, and $d$, with $a^{\prime \prime}, b^{\prime \prime}$, and $c^{\prime \prime}$ representing the corresponding phase-contrast photomicrographs to fluorescence images $a$ and $a^{\prime}, b$ and $b^{\prime}$, and $c$ and $c^{\prime}$, respectively. O4-positive cells avoid tenascin-rich areas $\left(a, a^{\prime} ; b, b^{\prime} ;\right.$ and $\left.d, d^{\prime}\right)$. In contrast, the distribution of cells is not significantly influenced by patterned fibronectin/polyornithine substrates $\left(c, c^{\prime}\right)$. Cells immunoreactive for the $\mathrm{O} 4$ antigen $(d)$ but not the $\mathrm{O} 1$ antigen $\left(d^{\prime}\right)$ are oligodendroglial progenitor cells (Trotter and Schachner, 1989) and also avoid tenascin-rich regions $\left(d, d^{\prime}\right)$. Scale bars, $50 \mu \mathrm{m}$.
} 
migrating oligodendrocyte progenitor cells, we have visualized oligodendrocyte progenitor cells with a PDGF $\alpha$-receptor cRNA probe (see Pringle et al., 1992; Mudhar et al., 1993). In the optic nerve, expression of PDGF $\alpha$-receptor appears to be restricted to the oligodendrocyte lineage, and it has been suggested that PDGF $\alpha$-receptor starts to be expressed by oligodendrocyte progenitor cells around the time that they begin migration and that expression is downregulated in young oligodendrocytes (Hart et al., 1989; Pringle et al., 1992; Mudhar et al., 1993; Pringle and Richardson, 1993). The spatiotemporal appearance of PDGF $\alpha$-receptor-positive cells that we observed in the developing mouse optic nerve is consistent with the idea that labeled cells correspond to migrating oligodendrocyte progenitor cells (Small et al., 1987; Fulton et al., 1992; Pringle et al., 1992; Mudhar et al., 1993). Our results demonstrate that oligodendrocyte progenitor cells reach the distal end of the retinal tenascin gradient not before postnatal day 3 . Thus, we conclude that migrating progenitor cells will come into contact with increasing tenascin concentrations at the retinal end of the nerve not only in adults but also during development at times compatible with a barrier function.

We have shown that tenascin, in contrast to the other two ECM molecules tested, laminin and fibronectin, is nonadhesive for oligodendrocytes and their progenitor cells when offered as substrate in a choice situation with polyornithine. It is therefore plausible to assume that the increased expression of tenascin at the retinal end of the devcloping and adult mouse optic nerve prevents migration of myelin-forming glial cells into the myelinfree proximal part of the nerve and into the retina. Ultrastructurally, tenascin is detectable in association with cell surfaces of astrocytes and unmyelinated retinal ganglion cell axons in the proximal segment of the adult optic nerve. Similarly, tenascin immunoreactivity is associated with all major cellular elements in the developing nerve (U. Bartsch et al., 1992). It is therefore reasonable to assume that migrating progenitor cells will become confronted with increasing concentrations of tenascin at the retinal end of the nerve.

Before and during the period of myelination, tenascin is strongly expressed in distal regions of the optic nerve (see also U. Bartsch et al., 1992). Here, tenascin is distributed in a "downhill" gradient, with highest concentrations at the chiasmal end and decreasing concentrations in more proximal regions of the nerve. This observation indicates that the presence of tenascin per se does not interfere with migration of myelin-forming glial cells. In fact, current experiments demonstrate that oligodendrocytes and their progenitor cells prepared from mouse optic nerve, cerebellum, or forebrain adhere and extend processes when cultured on a homogeneous tenascin substrate ( $P$. Pesheva, in preparation). That the function of a molecule might be dependent on its spatial distribution has been shown in several experiments. In the embryonic chick tectum, a repellent axonguiding activity has been identified that is distributed in a gradient along the anterior-posterior axis of the tectum. Retinal axons from the temporal half of the retina (which project to anterior parts of the tectum) or from the nasal half of the retina (which project to posterior parts of the tectum) were offered the choice to grow on tectal cells or membranes from the anterior or posterior part of the tectum, respectively. Whereas temporal retinal axons were repelled by material from the posterior tectum, nasal retinal axons behaved indifferently in these assays (Walter et al., 1987a,b). Interestingly, the repellent effects on temporal retinal axons only become apparent in choice experi- ments or when the repellent material was offered as an "uphill" gradient, but not when it was offered as a homogeneous substrate or as a "downhill" gradient (Walter et al., 1987a; Baier and Bonhoeffer, 1992). Tenascin in the distal region of the developing nerve may allow or even support active cell migration when present in an uniform distribution or as a "downhill" gradient, whereas the same molecule may prevent migration of cells into the proximal segment of the nerve where it is present as an "uphill" gradient. Such an interpretation is in agreement with in vitro observations demonstrating that neural crest cells prefer to migrate onto fibronectin-coated areas rather than onto tenascin- or mixed fibronectin/tenascin-coated areas in twochoice situations (Tan et al., 1987), although the migration rate of neural crest cells in no-choice situations is similar or even higher on tenascin-coated substrates than on fibronectin-coated substrates (Mackie et al., 1988; Halfter et al., 1989). The influence of tenascin on the migration of neural crest cells in vivo is unclear, and it is a matter of discussion whether the presence of the molecule in the rostral halves of sclerotomes correlates with migration of neural crest cells into these regions or whether tenascin is concentrated in the rostral halves of sclerotomes only after neural crest cells have entered these regions. In the one case, tenascin may support cell migration; in the other, it may prevent invasion of following neural crest cells (Tan et al., 1987; Mackie et al., 1988; Stern et al., 1989). The effects of tenascin on the behavior of neuronal growth cones are also dependent on whether the molecule is offered as a homogeneous substrate in a mixture with laminin or as sharp boundary with laminin. In choice experiments with laminin, tenascin is avoided by growth cones from dorsal root ganglion cells and retinal ganglion cells. However, when tenascin is offered as a homogeneous substrate, axonal elongation of dorsal root ganglion cells is accelerated whereas axonal elongation of retinal ganglion cells is inhibited (Taylor et al., 1993). Our hypothesis that only "uphill" gradients of tenascin have repellent properties for migrating glial cells implies that the "downhill" gradient in distal regions of the developing nerve might serve as a mechanism to direct migration of glial cells toward the retinal end of the nerve, by preventing backward migration toward the chiasm.

The combined observations of the present study provide evidence that a topographically differential expression of tenascin may be one of the determinants imposing a molecular barrier for the migration of oligodendrocyte progenitor cells and oligodendrocytes into the most proximal part of the nerve and into the retina, thercby cstablishing and maintaining the differential distribution of myelin along mouse retinal ganglion cell axons. This contention is supported by the observation that tenascin adsorbed to polyornithine, in contrast to laminin and fibronectin, the two other ECM molecules tested, is a nonadhesive substrate for oligodendrocytes and their progenitor cells in a choice situation. In favor of this hypothesis is the observation that the rabbit optic nerve is not demarcated by a tenascin boundary at the retinal end of the optic nerve and retinal ganglion cell axons are myelinated intraretinally (Berliner, 1931; Schnitzer, 1985).

Recently, a mouse mutant has been described in which the tenascin gene is disrupted. Based on a light microscopic analysis, this mouse appears to be anatomically and histologically normal (Saga et al., 1992). This result suggests that other molccules may compensate for the proposed functions of tenascin. It remains to be seen whether the lack of tenascin affects the distribution of myelin along retinal ganglion cell axons in this mutant. 


\section{References}

Baier H, Bonhoeffer F (1992) Axon guidance by gradients of a targetderived component. Science 225:472-475.

Bartsch S, Bartsch U, Dörries U, Faissner A, Weller A, Ekblom P, Schachner M (1992) Expression of tenascin in the developing and adult cerebellar cortex. J Neurosci 12:736-749.

Bartsch U, Kirchhoff F, Schachner M (1989) Immunohistological localization of the adhesion molecules L1, N-CAM, and MAG in the developing and adult optic nerve of mice. J Comp Neurol 284:451462.

Bartsch U, Kirchhoff F, Schachner M (1990) Highly sialylated N-CAM is expressed in adult mouse optic nerve and retina. J Neurocytol 19: 550-565.

Bartsch U, Bartsch S, Dörries U, Schachner M (1992) Immunohistological localization of tenascin in the developing and lesioned adult mouse optic nerve. Eur J Neurosci 4:338-352.

Berliner ML (1931) Cytologic studies on the retina. I. Normal coexistence of oligodendroglia and myelinated nerve fibers. Arch Ophthalmol (Copenh) 6:740-751.

Berry M, Hall S, Follows R, Wyse JPH (1989) Defective myelination in the optic nerve of the Browman-Wyse (BW) mutant rat. J Neurocytol 18:141-159.

Bourdon MA, Matthews TJ, Pizzo SV, Bigner DD (1985) Immunochemical and biochemical characterization of a glioma-associated extracellular matrix glycoprotein. J Cell Biochem 28:183-195.

Bronner-Fraser M (1988) Distribution and function of tenascin during cranial neural crest development in the chick. J Neurosci Res 21: 135-147.

Büssow H (1978) Schwann cell myelin ensheathing C.N.S. axons in the nerve fibre layer of the cat retina. J Neurocytol 7:207-214.

Chiquet M, Fambrough DM (1984a) Chick myotendinous antigen. I. A monoclonal antibody as a marker for tendon and muscle morphogenesis. J Cell Biol 98:1926-1936.

Chiquet M, Fambrough DM (1984b) Chick myotendinous antigen. II. A novel extracellular glycoprotein complex consisting of large disulfide-linked subunits. J Cell Biol 98:1937-1946.

Chiquet-Ehrismann R, Kalla P, Pearson CA, Beck K, Chiquet M (1988) Tenascin interferes with fibronectin action. Cell 53:383-390.

Chuong C-M, Crossin KL, Edelman GM (1987) Sequential expression and differential function of multiple adhesion molecules during the formation of cerebellar cortical layers. J Cell Biol 104:331-342.

Epperlein H-H, Halfter W, Tucker RP (1988) The distribution of fibronectin and tenascin along migratory pathways of the neural crest in the trunk of amphibian embryos. Development 103:743-756.

Erickson HP, Bourdon MA (1989) Tenascin: an extracellular matrix protein prominent in specialized embryonic tissues and tumors. Annu Rev Cell Biol 5:71-92.

Erickson HP, Inglesias JL (1984) A six-armed oligomer isolated from cell surface fibronectin preparations. Nature 311:267-269.

Faissner A, Kruse J (1990) J1/tenascin is a repulsive substrate for central nervous system neurons. Neuron 5:627-637.

french-Constant C, Raff MC (1986) Proliferating bipotential glial progenitor cells in adult rat optic nerve. Nature 319:499-502.

french-Constant C, Miller RH, Burne JF, Raff MC (1988) Evidence that migratory oligodendrocyte-type-2 astrocyte (O-2A) progenitor cells are kept out of the rat retina by a barrier at the eye-end of the optic nerve. J Neurocytol 17:13-25.

Flage T (1977) Permeability properties of the tissues in the optic nerve head region in the rabbit and the monkey. Acta Ophthalmol 55:652664.

Fulton BP, Burne JF, Raff MC (1992) Visualization of O-2A progenitor cells in developing and adult rat optic nerve by quisqualatestimulated cobalt uptake. J Neurosci 12:4816-4833.

Grumet M, Hoffman S, Crossin KL, Edelman GM (1985) Cytotactin, an extracellular matrix protein of neural and non-neural tissues that mediates glia-neuron interaction. Proc Natl Acad Sci USA 82:80758079.

Halfter W, Chiquet-Ehrismann R, Tucker RP (1989) The effect of tenascin and embryonic basal lamina on the behavior and morphology of neural crest cells in vitro. Dev Biol 132:14-25.

Hart IK, Richardson WD, Heldin C-H, Westermark B, Raff MC (1989) PDGF receptors on cells of the oligodendrocyte-type- 2 astrocyte $(\mathrm{O}-$ 2A) cell lineage. Development 105:595-603.

Hildebrand C, Remahl S, Waxman SG (1985) Axo-glial relations in the retina-optic nerve junction of the adult rat: electron-microscopic observations. J Neurocytol 14:597-617.

Husmann K, Faissner A, Schachner M (1992) Tenascin promotes cerebellar granule cell migration and neurite outgrowth by different domains in the fibronectin type III repeats. J Cell Biol 116:14751486.

Jung HJ, Raine CS, Suzuki K (1978) Schwann cells and peripheral nervous system myelin in the rat retina. Acta Neuropathol (Berl) 44 : 245-247.

Keilhauer G, Faissner A, Schachner M (1985) Differential inhibition of neurone-neurone, neurone-astrocyte and astrocyte-astrocyte adhesion by L1, L2 and N-CAM antibodies. Nature 316:728-730.

Kruse I, Keilhauer G, Faissner A. Timpl R, Schachner M (1985) The $\mathrm{J} 1$ glycoprotein -a novel nervous system cell adhesion molecule of the L2/HNK-1 family. Nature 316:146-148.

Lai C, Brow MA, Nave K-A, Noronha AB, Quarles RH, Bloom FE, Milner RJ, Sutcliffe JG (1987) Two forms of 1B236/myelin-associated glycoprotein, a cell adhesion molecule for postnatal neural development, are produced by alternative splicing. Proc Natl Acad Sci USA 84:4337-4341.

Laywell ED, Dörries U, Bartsch U, Faissner A, Schachner M, Steindler DA (1992) Enhanced expression of the developmentally regulated extracellular matrix molecule tenascin following adult brain injury. Proc Natl Acad Sci USA 89:2634-2638.

Lewis SA, Balcarek JM, Krek V, Shelanski M, Cowan NJ (1984) Sequence of a cDNA clone encoding mouse glial fibrillary acidic protein: structural conservation of intermediate filaments. Proc Natl Acad Sci USA 81:2743-2746.

Lochter A, Vaughan L, Kaplony A, Prochiantz A, Schachner M, Faissner A (1991) $\mathrm{J} 1 /$ tenascin in substrate-bound and soluble form displays contrary effects on neurite outgrowth. J Cell Biol 113:1159-1171.

Mackie EJ, Tucker RP, Halfter W, Chiquet-Ehrismann R, Epperlein HH (1988) The distribution of tenascin coincides with pathways of neural crest cell migration. Development 102:237-250.

McKinnon RD, Matsui T, Dubois-Dalcq M, Aaronson SA (1990) FGF modulates the PDGF-driven pathway of oligodendrocyte differentiation. Neuron 5:603-614.

Mudhar HS, Pollock RA, Wang C, Stiles CD, Richardson WR (1993) PDGF and its receptors in the developing rodent retina and optic nerve. Development 118:539-552.

Noble M, Murray K, Stroobant P, Waterfield MD, Riddle P (1988) Platelet-derived growth factor promotes division and motility and inhibits premature differentiation of the oligodendrocyte/type-2 astrocyte progenitor cell. Nature 333:560-562.

Palay SL, Chan-Palay V (1974) Cerebellar cortex. Cytology and organization. New York: Springer.

Perry VH, Hayes L (1985) Lesion-induced myelin formation in the retina. J Neurocytol 14:297-307.

Perry VH, Lund RD (1990) Evidence that the lamina cribrosa prevents intraretinal myelination of retinal ganglion cell axons. $J$ Neurocytol 19:265-272.

Pesheva P, Spiess E, Schachner M (1989) J1-160 and J1-180 are oligodendrocyte-secreted nonpermissive substrates for cell adhesion. J Cell Biol 109:1765-1778.

Prieto AL, Jones FS, Cunningham BA, Crossin KL, Edelman GM (1990) Localization during development of alternatively spliced forms of cytotactin mRNA by in situ hybridization. J Cell Biol 111:685-698.

Prieto AL, Andersson-Fisone C, Crossin KL (1992) Characterization of multiple adhesive and counteradhesive domains in the extracellular matrix protein cytotactin. J Cell Biol 1 19:663-678.

Pringle NP, Richardson WD (1993) A singularity of PDGF alpha receptor expression in the dorsoventral axis of the neural tube may define the origin of the oligodendrocyte lineage. Development 117: 525-533.

Pringle NP, Mudhar HS, Collarini EJ, Richardson WD (1992) PDGF receptors in the rat CNS: during late neurogenesis, PDGF $\alpha$-receptor expression appears to be restricted to glial cells of the oligodendrocyte lineage. Development 115:535-551.

Raff MC, Miller RH, Noble M (1983) A glial progenitor cell that develops in vitro into an astrocyte or an oligodendrocyte depending on the culture medium. Nature 303:390-396.

Richardson WD, Pringle N, Mosley MJ, Westermark B, Dubois-Dalcq $M$ (1988) A role for platelet-derived growth factor in normal gliogenesis in the central nervous system. Cell 53:309-319.

Riou J-F, Shi D-L, Chiquet M, Boucaut J-C (1990) Exogenous tenascin 
inhibits mesodermal cell migration during amphibian gastrulation. Dev Biol 137:305-317.

Saga Y, Yagi T, Ikawa Y, Sakakura T, Aizawa S (1992) Mice develop normally without tenascin. Genes Dev 6:1821-1831.

Schachner M, Kim SK, Zehnle R (1981) Developmental expression in central and peripheral nervous system of oligodendrocyte cell surface antigens ( $\mathrm{O}$ antigens) recognized by monoclonal antibodies. Dev Biol 83:328-338.

Schnitzer J (1985) Distribution and immunoreactivity of glia in the retina of the rabbit. J Comp Neurol 240:128-142.

Skoff RP, Knapp PE, Bartlett WP (1986) Astrocytic diversity in the optic nerve: a cytoarchitectural study. In: Astrocytes, Vol I, (Fedoroff S, Vemadakis A, eds), pp 269-291. New York: Academic.

Small RK, Riddle P, Noble M (1987) Evidence for migration of oligodendrocyte-type-2 astrocyte progenitor cells into the developing rat optic nerve. Nature 328:155-157.

Sommer I, Schachner M (1981) Monoclonal antibodies (O1 to O4) to oligodendrocyte cell surfaces: an immunocytological study in the central nervous system. Dev Biol 83:311-327.

Spring J, Beck K, Chiquet-Ehrismann R (1989) Two contrary functions of tenascin: dissection of the active sites by recombinant tenascin fragments. Cell 59:325-334.

Stern CD, Norris WE, Bronner-Fraser M, Carlson GJ, Faissner A, Keynes R.J, Schachner M (1989) J1/tenascin-related molecules are not responsible for the segmented pattern of neural crest cells or motor axons in the chick embryo. Development 107:309-319.

Sugimoto T, Fukuda Y, Wakakuwa K (1984) Quantitative analysis of a cross-sectional area of the optic nerve: a comparison between albino and pigmented rats. Exp Brain Res 54:266-274.

Tan S-S, Crossin KL, Hoffman S, Edelman GM (1987) Asymmetric expression in somites of cytotactin and its proteoglycan ligand is correlated with neural crest cell distribution. Proc Natl Acad Sci USA 84:7977-7981.

Taylor J, Pesheva P, Schachner M (1993) The influence of janusin and tenascin on growth cone behavior in. vitro. J Neurosci Res 35 : 347-362.

Trotter J, Schachner M (1989) Cells positive for the O4 surface antigen isolated by cell sorting are able to differentiate into astrocytes or oligodendrocytes. Dev Brain Res 46:115-122.

Trotter J, Bitter-Suermann D, Schachner M (1989) Differentiationregulated loss of the polysialylated embryonic form and expression of the different polypeptides of the neural cell adhesion molecule by cultured oligodendrocytes and myelin. J Neurosci Res 22:369-383.

Tso MOM, Shih C-Y, McLean MIW (1975) Is there a blood-brain barrier at the optic nerve head? Arch Ophthalmol (Copenh) 93:815825.

Tsukamoto T, Kusakabe M, Saga Y (1991) In situ hybridization with non-radioactive digoxigenin-1 1-UTP-labeled cRNA probes: localization of developmentally regulated mouse tenascin mRNAs. Int J Dev Biol 35:25-32.

Tucker RP, McKay SE (1991) The expression of tenascin by neural crest cells and glia. Development 112:1031-1039.

Walter J, Kern-Veits B, Huf J, Stolze B, Bonhoeffer F (1987a) Recognition of position-specific properties of tectal cell membranes by retinal axons in vitro. Development 101:685-696.

Walter J, Henke-Fahle S, Bonhoeffer F (1987b) Avoidance of posterior tectal membranes by temporal retinal axons. Development 101:909913.

Wehrle B, Chiquet M (1990) Tenascin is accumulated along developing peripheral nerves and allows neurite outgrowth in vitro. Development 110:401-415.

Wolswijk G, Noble M (1989) Identification of an adult-specific glial progenitor cell. Development 105:387-400.

Wolswijk G, Riddle PN, Noble M (1991) Platelet-derived growth factor is mitogenic for O-2A ${ }^{\text {adult }}$ progenitor cells. Glia 4:495-503.

Wren D, Wolswijk G, Noble M (1992) In vitro analysis of the origin and maintenance of O-2A $A^{\text {adut }}$ progenitor cells. J Cell Biol 116:167176.

Wyse JPH (1980) Schwann cell myelination in the nerve fibre layer of the BW rat retina. J Neurocytol 9:107-117.

Wyse JPH, Spira AW (1981) Ultrastructural evidence of a peripheral nervous system pattern of myelination in the avascular retina of the guinea pig. Acta Neuropathol (Berl) 54:203-210. 